Prepared in cooperation with the International Joint Commission

\title{
Estimates of Long-Term Mean-Annual Nutrient Loads Considered for use in SPARROW Models of the Midcontinental Region of Canada and the United States, 2002 Base Year
}

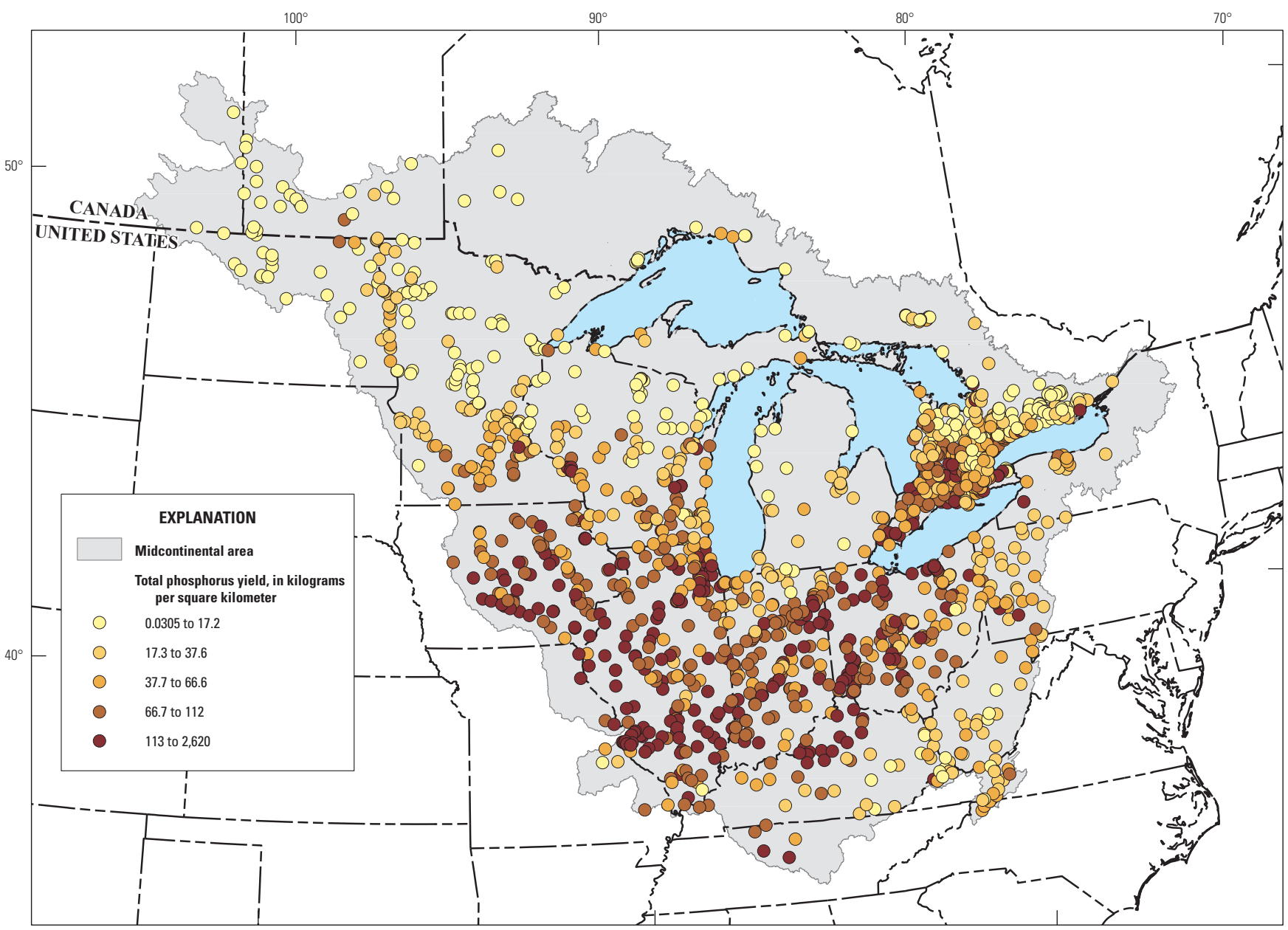

Scientific Investigations Report 2018-5051 
Cover. Map shows total phosphorus yield for stream sites considered for inclusion in the 2002 Midcontinent SPARROW total phosphorus model. 


\section{Estimates of Long-Term Mean-Annual Nutrient Loads Considered for use in SPARROW Models of the Midcontinental Region of Canada and the United States, 2002 Base Year}

By David A. Saad, Glenn A. Benoy, and Dale M. Robertson

Prepared in cooperation with the International Joint Commission

Scientific Investigations Report 2018-5051 


\title{
U.S. Department of the Interior \\ RYAN K. ZINKE, Secretary
}

\section{U.S. Geological Survey William H. Werkheiser, Deputy Director exercising the authority of the Director}

\author{
U.S. Geological Survey, Reston, Virginia: 2018
}

For more information on the USGS - the Federal source for science about the Earth, its natural and living resources, natural hazards, and the environment-visit https://www.usgs.gov or call 1-888-ASK-USGS.

For an overview of USGS information products, including maps, imagery, and publications, visit https://store.usgs.gov.

Any use of trade, firm, or product names is for descriptive purposes only and does not imply endorsement by the U.S. Government.

Although this information product, for the most part, is in the public domain, it also may contain copyrighted materials as noted in the text. Permission to reproduce copyrighted items must be secured from the copyright owner.

Suggested citation:

Saad, D.A., Benoy, G.A., and Robertson, D.M., 2018, Estimates of long-term mean-annual nutrient loads considered for use in SPARROW models of the Midcontinental region of Canada and the United States, 2002 base year: U.S. Geological Survey Scientific Investigations Report 2018-5051, 14 p., https://doi.org/10.3133/sir20185051.

ISSN 2328-0328 (online) 


\section{Acknowledgments}

The authors acknowledge the numerous Federal, State, Provincial, and regional government agencies and Universities that contributed water-quality and streamflow data to this study. The contributing organizations in the United States are listed in Saad and others (2011); contributing organizations in Canada are listed in this report. Special thanks are due to the water-quality and hydrometric specialists with Federal and Provincial agencies in Canada who facilitated access to their databases and provided expertise on their monitoring programs: Craig McCrimmon, Isaac Wong, and Erika Klyszejko of Environment and Climate Change Canada; Pam Minifie of the Saskatchewan Ministry of the Environment; Elaine Page of Manitoba Sustainable Development; and Georgina Kaltenecker of the Ontario Ministry of the Environment and Climate Change. Funding for this study was provided by the International Joint Commission. 



\section{Contents}

Acknowledgments ……...................................................................................................................

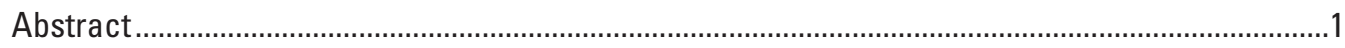

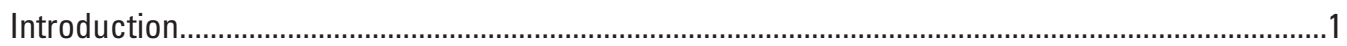

Water-Quality Modeling........................................................................................................

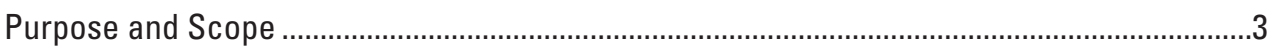

Water-Quality and Streamflow Data used to Estimate Long-Term Mean-Annual

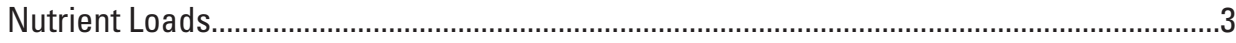

Water-Quality Data ……....................................................................................................

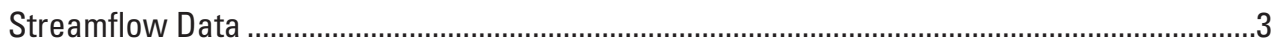

Protocols for Screening Water-Quality and Streamflow Sites ...................................................

Protocols for Matching a Water-Quality Site to a Streamgage ................................................

Methods for Estimating Long-Term, Mean-Annual Nutrient Loads ...............................................

Final Loads Considered for use in the 2002 Midcontinent Total Phosphorus and

Total Nitrogen SPARROW Models.......................................................................................

Site Counts and Quality of Load Estimates..............................................................................

Site Distribution and Mean-Annual Nutrient Yields.................................................................

Summary

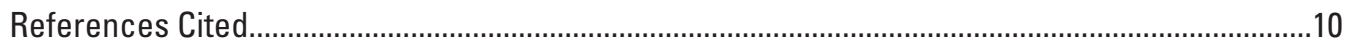

Appendix 1. Sampling Agencies Associated with Water-Quality Data used to Calculate Load Estimates Considered for use in 2002 Midcontinent SPARROW Models....................14

\section{Figures}

1. Map showing extent of the Midcontinent SPARROW model area in Canada

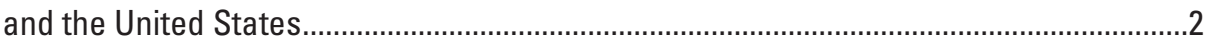

2. Map showing total nitrogen yield for stream sites considered for inclusion in the 2002 Midcontinent SPARROW total nitrogen model .............................................

3. Map showing total phosphorus yield for stream sites considered for inclusion in the 2002 Midcontinent SPARROW total phosphorus model. .9

\section{Table}

1. Counts of nutrient water-quality sites throughout the screening process to estimate TN and TP loads in the Midcontinental region. 


\section{Conversion Factors}

International System of Units to U.S. customary units

\begin{tabular}{lcl}
\hline \multicolumn{1}{c}{ Multiply } & By & \multicolumn{1}{c}{ To obtain } \\
\hline meter $(\mathrm{m})$ & Length & foot $(\mathrm{ft})$ \\
kilometer $(\mathrm{km})$ & 3.281 & mile $(\mathrm{mi})$ \\
\hline & 0.6214 & \\
\hline square kilometer $\left(\mathrm{km}^{2}\right)$ & Area & square mile $\left(\mathrm{mi}^{2}\right)$ \\
\hline & 0.3861 & gallon $(\mathrm{gal})$ \\
\hline liter $(\mathrm{L})$ & Volume & \\
\hline & 0.2642 & ounce, avoirdupois $(\mathrm{oz})$ \\
\hline gram $(\mathrm{g})$ & Mass & pound, avoirdupois $(\mathrm{lb})$ \\
kilogram $(\mathrm{kg})$ & 0.03527 & \\
\hline & 2.205 & cubic foot per second $\left(\mathrm{ft}^{3} / \mathrm{s}\right)$ \\
\hline cubic meters per second $\left(\mathrm{m}^{3} / \mathrm{s}\right)$ & Flow rate \\
\hline
\end{tabular}




\title{
Estimates of Long-Term Mean-Annual Nutrient Loads Considered for use in SPARROW Models of the Midcontinental Region of Canada and the United States, 2002 Base Year
}

\author{
By David A. Saad', Glenn A. Benoy², and Dale M. Robertson¹
}

\section{Abstract}

Streamflow and nutrient concentration data needed to compute nitrogen and phosphorus loads were compiled from Federal, State, Provincial, and local agency databases and also from selected university databases. The nitrogen and phosphorus loads are necessary inputs to Spatially Referenced Regressions on Watershed Attributes (SPARROW) models. SPARROW models are a way to estimate the distribution, sources, and transport of nutrients in streams throughout the Midcontinental region of Canada and the United States. After screening the data, approximately 1,500 sites sampled by 34 agencies were identified as having suitable data for calculating the long-term mean-annual nutrient loads required for SPARROW model calibration. These final sites represent a wide range in watershed sizes, types of nutrient sources, and land-use and watershed characteristics in the Midcontinental region of Canada and the United States.

\section{Introduction}

Excessive nutrients have been a persistent problem in streams, lakes, and estuaries throughout the Midcontinental region of Canada and the United States (Carpenter and others, 1998; U.S. Environmental Protection Agency, 1998; Smith, 2003; Dodds and Smith, 2016; fig. 1). The region includes the binational Red-Assiniboine River, Rainy-Lake of the Woods, and Great Lakes Basins as well as the neighboring Winnipeg River Basin in Canada and the Upper Mississippi River and Ohio River Basins within the United States (fig. 1). Excessive loading of phosphorus and nitrogen from anthropogenic sources has been linked to algal blooms and hypoxia in Lake Winnipeg, Lake of the Woods, Lake Erie, and other sections of the Great Lakes, including Green Bay and Saginaw Bay

${ }^{1}$ U.S. Geological Survey.

${ }^{2}$ International Joint Commission.
(Schindler and others, 2012; Michalak and others, 2013; Clark and Sellers, 2014). Hypoxia in the Gulf of Mexico has been associated with nitrogen $(\mathrm{N})$ and phosphorus $(\mathrm{P})$ loading from the Mississippi River, including contributions from the Upper Mississippi River and Ohio River Basins (U.S. Environmental Protection Agency, 2000).

\section{Water-Quality Modeling}

To help understand the distribution, origin, and sources of nutrients (total nitrogen [TN] and total phosphorus [TP]), SPAtially Referenced Regressions On Watershed attributes (SPARROW) water-quality models have previously been developed for specific parts of this region (Robertson and Saad, 2011, 2013; Benoy and others, 2016). Now, SPARROW models are being developed to address nutrient issues throughout the entire Midcontinental region.

SPARROW models simulate long-term mean-annual nutrient or other loads of interest in streams and rivers over large geographic areas (Preston and others, 2009). The models can be used to help understand the origin and transport of the major sources of nutrients or other types of contaminants. The Midcontinent nutrient SPARROW models will use readily available source and watershed characteristic spatial datasets, a binational, harmonized digital stream network based on the National Hydrography Data (NHDPlus Version 2; Moore and Dewald, 2016) in the United States and the National Hydro Network (Natural Resources Canada, 2009) in Canada and the long-term mean-annual loads described in this report.

SPARROW models are calibrated using long-term mean-annual estimates of specific loads such as nutrients based on available monitoring data. A set of load monitoring sites representing a wide range of watershed characteristics is required to develop and calibrate the Midcontinent SPARROW models. In the United States, TP and TN load estimates for SPARROW models are primarily derived from data readily available in national databases. For this binational application, additional steps were required to acquire streamflow and water-quality data from Federal, Provincial, and local 


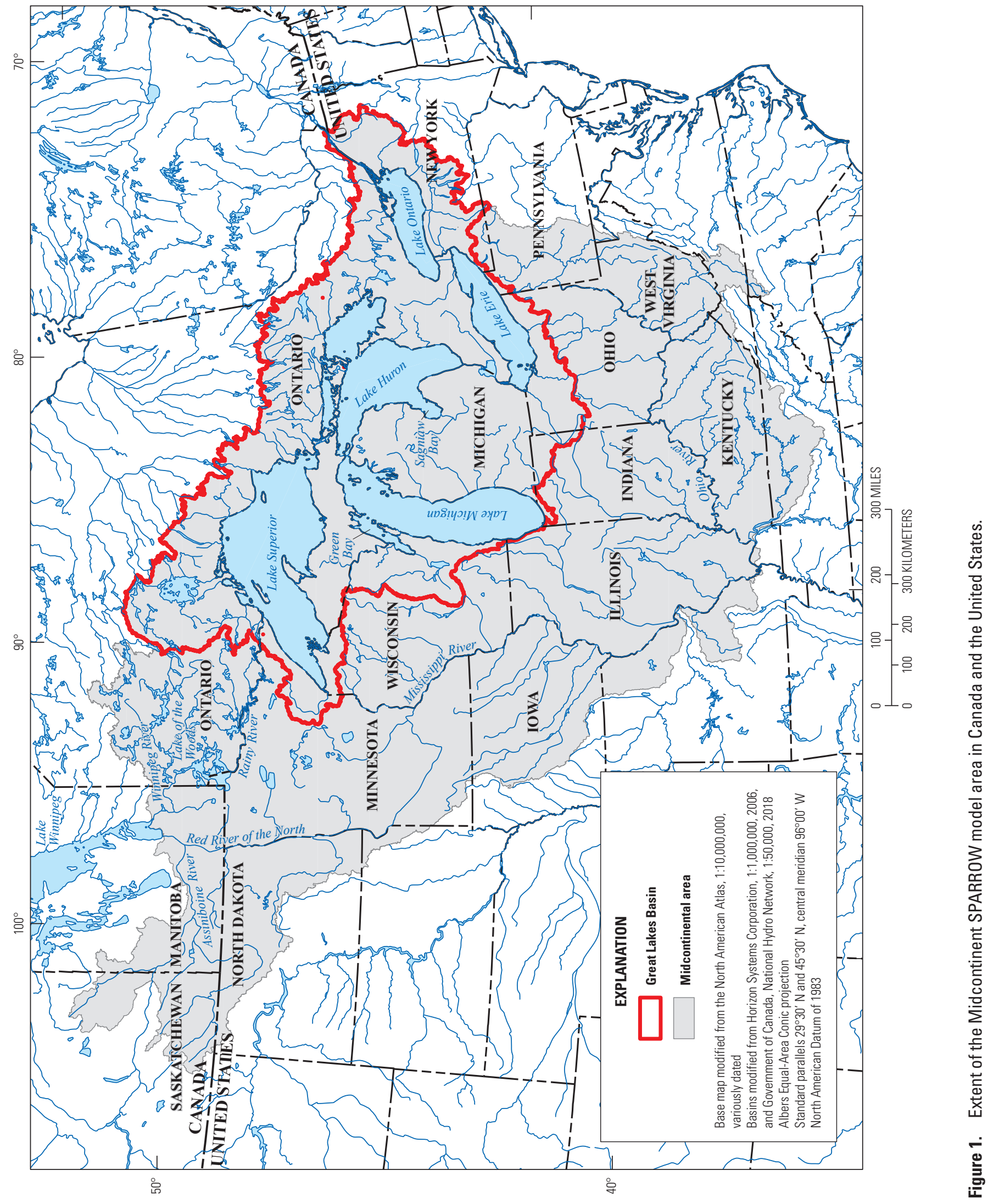


agencies in Canada. Once the databases from both countries were obtained and combined, common techniques were used to generate a consistent set of loads across the spatial extent of the Midcontinental region.

\section{Purpose and Scope}

The purpose of this report is to describe the detailed approach of assembling, processing, and utilizing available streamflow and water-quality data needed to compute longterm mean-annual TP and TN loads at monitoring sites. Load estimation methods and criteria for selecting the final set of loads considered for use in the Midcontinent SPARROW models are described. Maps of nutrient yields (loads normalized by watershed area) are presented to show the distribution of TP and TN in streams throughout the Midcontinental region of Canada and the United States. The dataset of all load model inputs and outputs is available online (Saad and others, 2018; https://doi.org/10.5066/F7VT1R1K).

\section{Water-Quality and Streamflow Data used to Estimate Long-Term Mean- Annual Nutrient Loads}

The dependent variable in SPARROW water-quality models is long-term mean-annual loads (for example, TP or TN) normalized to a specific base year (Preston and others, 2009). The base year for the Midcontinent SPARROW models is 2002, which was selected so that estimated loads would coincide with available geospatial datasets describing water-quality data sources and environmental characteristics. Mean-annual loads were estimated using data derived from water-quality samples and continuous (daily) measures of streamflow for each monitoring site. Descriptions of the water-quality and streamflow data are given in the "WaterQuality Data" and "Streamflow Data" sections of this report. A detailed description of the load-computation methods is included in the "Methods for Estimating Long-Term, MeanAnnual Nutrient Loads" section of this report.

\section{Water-Quality Data}

Previous evaluations of SPARROW models have determined that increasing the number of sites with estimated loads that represent a range in watershed attributes increases the level of certainty in SPARROW load estimations for streams throughout the modeled basin (Saad and others, 2011; Preston and others, 2009; Schwarz and other, 2006). To maximize the number of monitoring sites that could be included in the 2002 Midcontinent SPARROW models, water-quality monitoring data from many Federal, State and Provincial, and regional government agencies and nongovernmental organizations in
Canada and the United States were inventoried, evaluated, and compiled. The foundations for this binational inventory were the U.S. Geological Survey National Water Information System (NWIS), the U.S. Environmental Protection Agency STOrage and RETrieval (STORET) system, the Ontario Ministry of the Environment and Climate Change Provincial Water-Quality Monitoring Network (PWQMN), the Environment and Climate Change Canada Aquatic Chemistry and Biological Information System (ACBIS), the Manitoba Sustainable Development water-quality database, and the Saskatchewan Ministry of the Environment Environmental Management System (SEEMS), which are among the largest databases of water-quality records available in the United States and Canada. In addition to the preceding databases, data were also compiled from many regional and local online water-quality data delivery systems that were readily available to the public. The effort to inventory water-quality data also included working directly with State, Provincial, and local water resource agencies to acquire relevant water-quality records that were available in electronic format but were not available in other public, online databases. Water-quality data considered for load estimates included the period from 1970 through 2012, where available. This period was chosen to provide an accurate representation of long-term mean annual loads and to include data before and after the base year. A list of agencies contributing water-quality data described in this report are included in appendix 1.

The primary concentrations used in load calculations were unfiltered TN as N and unfiltered TP as P, both expressed in units of milligrams per liter. If the concentration of $\mathrm{TN}$ was not available, it was calculated as the sum of particulate and dissolved (filtered) forms of measured $\mathrm{N}$, if those data were available. Where total or particulate and dissolved measurements of $\mathrm{N}$ were unavailable, $\mathrm{TN}$ was calculated as the sum of the concentrations of ammonium, organic $\mathrm{N}$, and nitrite plus nitrate (or just nitrate) where possible. TP was based primarily on TP concentrations reported as $\mathrm{P}$, however, some TP data were reported as phosphate $\left(\mathrm{PO}_{4}^{3-}\right)$ and converted to $\mathrm{P}$. The specific forms of $\mathrm{N}$ and $\mathrm{P}$ considered when estimating the concentrations of TN and TP, and the protocols for combining those concentrations, are described in the Supporting Information of Saad and others (2011) and Jenkinson and Benoy (2015).

\section{Streamflow Data}

Mean daily streamflows for the period from October 1, 1970, through September 30, 2012, where available, were used to calculate loads considered for use in the Midcontinent SPARROW models. These data were compiled from the U.S. Geological Survey NWIS database (U.S. Geological Survey, 2017) and the Environment and Climate Change Canada HYDAT database (Environment and Climate Change Canada, 2016). 


\section{Protocols for Screening Water-Quality and Streamflow Sites}

Once the water-quality and streamflow datasets were compiled, a screening process, similar to that described in Saad and others (2011), was completed to identify monitoring sites with sufficient data for computing loads. Screening criteria included minimum requirements for availability of waterquality data, the ability to confirm the location of the site and index it to the digital stream network used in the models, and the ability to associate the water-quality site with a nearby streamgage. Additional evaluation of the calculated loads (described in the section "Methods for Estimating Long-Term, Mean-Annual Nutrient Loads") ensured that only the most suitable load estimates were considered for use as calibration targets in the SPARROW models.

The data requirements for streamgages used for load calculations included a minimum record length of 2 years of daily streamflows and the period must include 2002. The minimum water-quality data requirements for computing loads at a site included a minimum record length of 2 years and at least $25 \mathrm{TN}$ or TP samples. If the water-quality record was less than 5 years, the water-quality period of record also had to be within 2 years of the 2002 base year. If the water-quality record was 5 years or more, data had to be within 7 years of the base year. These minimum requirements were evaluated by using the data available at a site for the period from October 1, 1970, through September 30, 2012. Water-quality sites meeting these minimum requirements were referred to as "potential load sites." The location of each potential load site was manually checked and indexed to the digital stream networks used in the SPARROW models. If the description of a waterquality site (including name and watershed area) matched the mapped location (based on the digital network stream name and watershed area attributes, or using digital topographic maps, or both), the site was indexed to the stream network. If a site location could not be reasonably verified, the site was excluded from further consideration.

\section{Protocols for Matching a Water-Quality Site to a Streamgage}

Estimates of load require extended periods of coinciding concentration and streamflow data. Matching a potential load site to a nearby streamgage initially involved identifying streamgages that met minimum data requirements for streamflow and then selecting the streamgage with streamflow characteristics that best represented those at the water-quality monitoring location. Load calculations are ideally done using collocated water-quality and streamflow sites; however, use of a nearby streamgage is a common approach when collocation is not possible. Where collocation was not possible, streamflow was adjusted based on the ratio of the water-quality site to streamflow site watershed areas. The following criteria were used to identify suitable streamgages for a nearby waterquality site:

1. Overlap between water-quality and streamflow data had to be at least 2 years;

2. The ratio of watershed areas between the water-quality site and streamflow site is between 0.75 and 1.33 ;

3. If the watershed area of the water-quality site was greater or equal to 260 square kilometers $\left(\mathrm{km}^{2}\right)$ then the streamgage must be on the same stream;

4. If the watershed area of the water-quality site was less than $260 \mathrm{~km}^{2}$, then the streamgage could be on a nearby stream; and

5. The streamgage must be within a reasonable distance (areal distance less than or equal to 40 kilometers [km]) of the water-quality site so as to represent similar environmental conditions.

If a potential load site had multiple, nearby, suitable streamgages, priority for selection was given to streamgages with a longer period of data overlap, watershed area ratios closer to 1 , and a shorter distance to the water-quality site (Saad and others, 2011).

\section{Methods for Estimating Long-Term, Mean-Annual Nutrient Loads}

SPARROW models require long-term, mean-annual loads for calibration. For sites having significant trends in load, loads were detrended to the base year (2002). Detrending allows for better comparison of loads among sites with monitoring data that cover different time periods (Preston and others, 2009; Schwarz and others, 2006).

A variety of methods are available to estimate longterm, mean-annual loads. Lee and others (2016) evaluated 11 methods for estimating long-term mean-annual loads for specific conductance, nitrate, TN, TP, and suspended sediment. Of the methods evaluated by Lee and others (2016), the Beale ratio-estimator (BRE) method (Cochran, 1977) performed the best. Five-parameter regression and weighted regression methods also did reasonably well. Only two of the programs evaluated, Fluxmaster (regression, Schwarz and others, 2006) and WRTDS (weighted regression, Hirsch and others, 2010), were capable of estimating detrended, long-term, mean-annual loads. A limiting factor with WRTDS is that this method generally requires extensive water-quality data (at least 100 observations) for long periods of time (greater than 10 years) to produce accurate estimates of load. Many of the sites used in this effort do not have enough data or do not cover a period of time long enough to consider using WRTDS. Only one of the programs, Fluxmaster, estimates loads using both the BRE and regression methods from a single dataset. Therefore, loads 
considered for use in the Midcontinent SPARROW models were estimated using the Fluxmaster program.

For this effort, long-term mean-annual loads for nutrients at each site, were estimated by using both the BRE and Fluxmaster 5-parameter regression (F5) methods. The BRE method was implemented in stratified form as described in Cochran (1977). In this application, as much as eight strata were formed by subdividing streamflow into two classes (delineated by the 80th percentile of streamflow) and subdividing the year into four seasons (January through March, April through June, July through September, and October through December) after combining all data among years. If the number of samples within any strata was less than 10 , then the strata were collapsed following the protocol described in Lee and others (2016). The Beale ratio of a given stratum is the ratio of the stratum sample means of load and streamflow (eq. 1 in Lee and others, 2016). The estimate of load for all days within a stratum is given by the sum of measured daily loads plus the product of the estimated Beale ratio for the stratum multiplied by the total streamflow for all unsampled days in the stratum. The summation of these estimates across all strata then gives the BRE load estimate for all days in the prediction period. The BRE method, as implemented here, produces nondetrended, long-term mean-annual loads.

Detrended long-term mean-annual loads were computed with regression methods developed by Cohn (2005) and implemented in Fluxmaster. The regression-based load estimates are based on a 5-parameter water-quality model (eq. 1) that relates the logarithm of concentration at time $t\left(c_{t}\right)$, to the logarithm of daily streamflow, a decimal time term, and sine and cosine functions of decimal time to account for seasonal variation, and a model residual:

$$
c_{t}=b_{0}+b_{\mathrm{q}} q_{t}+b_{T} T_{t}+b_{s} \sin \left(2 \pi T_{t}\right)+b_{c} \cos \left(2 \pi T_{t}\right)+e_{t},
$$

where

$q_{t} \quad$ is the logarithm of daily flow,

$T_{t} \quad$ is the decimal time term,

$e_{t} \quad$ is the model residual, and

$b_{0}, b_{q}, b_{T}, b_{s}$, and $b_{c}$ are coefficients estimated for each site by the ordinary least squares method, or by the adjusted maximum likelihood method (Cohn, 2005) if some of the $c_{t}$ measurements are censored.

The residuals, $e_{t}$, are assumed to be independent and normally distributed with mean $=0$ and variance $=\sigma_{e}^{2}$.

Detrending was used to remove long-term changes in the data, not cyclical or short-term variations such as year-to-year differences caused by variability in meteorology (Schwarz and others, 2006). Average streamflow can vary widely from year to year, so a sufficiently long period of record is needed to identify long-term trends that are not masked by shortterm meteorological variations. For this analysis, the authors considered 20 years of streamflow record to be sufficient for estimating long-term trends in streamflow. Considering the 20-year threshold, detrended loads were computed using two methods, depending on the length of the streamflow record used for prediction. For streamflow records of 20 years or less, loads were computed using only detrended concentrations. For streamflow records greater than 20 years, loads were computed using detrended concentrations and detrended streamflows.

The following is a detailed description of these methods.

For streamflow records of more than 20 years, detrended streamflow was estimated using equation 2 :

$$
q_{t}=a_{0}+a_{T} T_{t}+a_{s} \sin \left(2 \pi \mathrm{T}_{t}\right)+a_{c} \cos \left(2 \pi \mathrm{T}_{t}\right)+u_{t},
$$

where

$$
\begin{gathered}
a_{0}, a_{T}, a_{T}, \text { and } a_{c} \text { are coefficients estimated using the maximum } \\
\text { likelihood SAS Autoreg procedure (SAS } \\
\text { Institute Inc., 2004), and } \\
\begin{aligned}
u_{t} \quad \text { is the model residual that is assumed to be } \\
\text { correlated across time according to a } \\
\text { 30-day lag autoregressive model. }
\end{aligned}
\end{gathered}
$$

Final detrended flows $\left(\tilde{q}_{t}\right)$ were then estimated using equation 3:

$$
\tilde{q}_{t}=q_{t}+a_{T}\left(T_{b}-T_{t}\right)
$$

where

$$
\begin{gathered}
T_{b} \quad \text { is } 2002.5 \text { (which is used by Fluxmaster to } \\
\text { represent June } 30 \text { of the base year). }
\end{gathered}
$$

For streamflow records of 20 years or less, the logarithm of detrended daily concentrations were computed using equation 1 with $T_{b}$ substituted for $T_{t}$. For streamflow records greater than 20 years, $T_{b}$ and $\tilde{q}_{t}$ were substituted for $T_{t}$ and $q_{t}$. The logarithm of detrended daily concentrations were then added to the logarithm of daily streamflow (detrended or nondetrended) to obtain the detrended logarithm of daily load. These load estimates were then converted from logarithm space to real space using methods described by Cohn (2005) and Schwarz and others (2006). For both the BRE and regression method load estimates, the long-term mean-annual load was computed by identifying those years included in the analysis period that had no days with missing streamflows, summing the daily load estimates for those years, and dividing by the number of included years to obtain mean-annual load in units of kilograms per year.

Load estimates were evaluated for trend, accuracy and bias prior to finalizing selected loads considered for inclusion as calibration targets in the SPARROW models. In general, the selected load estimate for a site was based on if there was a significant trend in load. If there was no significant trend, the BRE long-term, mean-annual load was selected as the final load. If there was a significant $(p<0.05)$ trend in load, the authors generally used the detrended F5 estimate as the final load. The only time detrended load was not used where the trend was significant was if the water-quality period of record was centered near the base year (somewhere within 2002). Detrending essentially pivots the load estimates for the period of record around the base year (Schwarz and others, 2006). If the base year is near the beginning or end of the period of 
record, the detrended mean-annual load can be quite different from the mean-annual load. When the period of record is centered near the 2002 base year, the detrended mean-annual load should be similar to the mean-annual load. In the case of a site with a significant trend, but the period of record is centered near the base year, the BRE and detrended F5 methods should both produce load estimates that are acceptable for SPARROW modeling. In these cases, the BRE method is preferred because of better overall performance in estimating long-term mean-annual loads (Lee and others, 2016).

In addition to trend, load estimates were evaluated for accuracy and bias (for sites with significant trend in load) prior to final selection for consideration as SPARROW model calibration targets. Sites with poor accuracy and large bias were excluded from consideration for use in SPARROW models. The standard error of a load model estimate provides a measure of the accuracy of the load model predictions. Standard errors within 50 percent of the mean load estimate were considered acceptable and are consistent with the accuracy level used in previous SPARROW modeling studies (Saad and others, 2011).

Bias provides a description of whether the predicted loads are systematically too high or too low relative to the observed loads. Load estimation methods done in log space, such as many of the regression methods (including F5), can have biased results when the estimations are converted back into real space because of one or both of the following: (1) heteroscedasticity in the residuals from the model and (2) the statistical relation between streamflow and concentration overestimating or underestimating concentrations for certain streamflow regimes. One of the underlying assumptions of log-based regression models is that the residuals are normally distributed and have a constant variance (Runkel and others, 2004). If the residuals do not have constant variance (for example, they have a heteroscedastic distribution) the retransformation process (converting predictions from log space into real space) can lead to biased predictions (Hirsch, 2014). All of the computations using the BRE method are done in real space and should not produce biased results like those associated with retransformation. For this reason, comparing the F5 load to the BRE load should be a good way of evaluating bias in the F5 load. Evaluation of bias was only done for sites with significant trend in load, where the F5 load estimate was being considered as the final load. Bias (R) in a F5 regression estimate, calculated as the ratio BRE load estimate divided by the F5 load estimate, was considered minimal when R is near 1.0; An R between 0.66 and 1.5 was considered acceptable. The selection of this range was chosen to be similar in magnitude to the 50 percent criteria used for model accuracy. For detrended loads, R can deviate from 1.0 even if the load estimate has no bias. The amount of deviation depends on the magnitude of the trend and the proximity of the water-quality period of record compared to the base year. For sites with significant trends, an adjustment to the acceptable bias range was required to account for this deviation. The trend-adjusted acceptable bias range was increased by a factor m (eq. 4):

$$
m=\exp \left(k^{*} y r d i f\right)
$$

where

$k \quad$ is equal to the absolute value of the trend in
the load (expressed as a fraction of the
mean load estimate per year), and
is equal to the absolute value of (2002.5-
midyear of the water-quality period of
record).

Therefore, $\mathrm{R}$ could fall into a range of $\mathrm{m}$ divided by 1.5 to $\mathrm{m}$ multiplied by 1.5 . As the magnitude of the trend gets smaller and the midyear of the water-quality record approaches the base year, $m$ approaches 1.0. This adjustment assumes that the water-quality samples were approximately equally spaced throughout the sample period, which is not always the case.

For each site and nutrient, the following decision steps summarize the process of deciding which load estimation should be considered for inclusion in the Midcontinent SPARROW models:

1. Is the trend in load significant and the water-quality period of record not centered within the 2002 base year?

2. If the answer to (1) is "no," then evaluate the BRE load estimate for this site. If the standard error for the BRE load estimate is less than 0.5 , consider including this load in the SPARROW model, if the standard error is greater than or equal to 0.5 exclude this load.

3. If the answer to (1) is "yes," then evaluate the detrended F5 regression load estimate for this site. If the standard error for the F5 load is less than 0.5 and the bias is within the acceptable range of $\mathrm{m}$ divided by 1.5 to $\mathrm{m}$ multiplied by 1.5 , consider including this load in the SPARROW model, otherwise exclude this load.

The final load estimates for TP and TN, load model coefficients, and other associated information for each site, are included in the online dataset associated with this report (Saad and others, 2018). 


\section{Final Loads Considered for use in the 2002 Midcontinent Total Phosphorus and Total Nitrogen SPARROW Models}

The initial compilation of $\mathrm{N}$ and $\mathrm{P}$ data consisted of observations from approximately 35,000 stream sites. Only about 12 percent of those sites, however, met the minimum water-quality screening criteria, and only about 4 percent of the initial sites had data considered adequate for calculating TP or TN loads.

\section{Site Counts and Quality of Load Estimates}

A summary of the number of monitoring stations, by country, at each major step in the evaluation process, is listed in table 1. The final sites, reflecting all of the stated qualifications, is composed of water-quality observations from 1,323 TN sites and 1,472 TP sites from 34 agencies (appendix 1).

Most of the final load estimates considered for use in the 2002 Midcontinent SPARROW TN and TP models were based on the BRE method. Approximately 72 and 71 percent of the TN and TP load estimates, respectively, considered for use in the models were based on the BRE method. Although the maximum allowable standard error was 50 percent of the mean estimate, the average ranged from approximately 8 percent for TN to 14 percent for TP. In general, the standard errors were slightly larger for the BRE estimates than the F5 load estimates. Additionally, although the acceptable bias $\mathrm{R}$ range was from about 0.66 to 1.5 , the average for sites with a significant trend in load, ranged from 0.98 for TN to 1.22 for
TP. This range indicates that, on average BRE load estimates were nearly the same as detrended F5 regression load estimates for TN and slightly higher for TP.

\section{Site Distribution and Mean-Annual Nutrient Yields}

The final TN and TP load sites considered for inclusion in the 2002 Midcontinent SPARROW models represent a wide range in watershed sizes, nutrient source inputs, and land-use and watershed characteristics in the model area (figs. 2 and 3 ). The distribution of TN and TP load sites cover most of the area; however, the density of sites is low in the northern portions of Michigan and Minnesota and very low in Ontario and north of Lakes Huron and Superior. In southeast Ontario, between Lakes Huron and Erie, the density of sites is greater than any other location in the model area. TN yields from these sites range from less than 1 kilogram per square kilometer $\left(\mathrm{kg} / \mathrm{km}^{2}\right)$ to greater than $69,000 \mathrm{~kg} / \mathrm{km}^{2}$; TP yield ranges from less than $1 \mathrm{~kg} / \mathrm{km}^{2}$ to greater than $2,600 \mathrm{~kg} / \mathrm{km}^{2}$. The area with the largest TN and TP yields is a band that stretches from Iowa; through Illinois, Indiana, and Ohio; and into southeast Ontario. Agriculture is the primary land use in this area, but this area also includes some of the largest cities in North America. The smallest TN and TP yields are in the north, northwest, and southeast portions of the model area. The north and southeast areas are typically more forested, with relatively small TN and TP source inputs. The northwest, primarily the Red-Assiniboine River Basin, is dominated by agriculture with relatively large $\mathrm{N}$ and $\mathrm{P}$ inputs, but the northwest is also the driest part of the Midcontinental region, which results in relatively low yields.

Table 1. Counts of nutrient water-quality sites throughout the screening process to estimate TN and TP loads in the Midcontinental region.

[TN, total nitrogen; TP, total phosphorus]

\begin{tabular}{lccc}
\hline Country & $\begin{array}{c}\text { Sites with nutrient } \\
\text { water-quality data }\end{array}$ & $\begin{array}{c}\text { Nutrient sites meeting minimum } \\
\text { water-quality screening criteria }\end{array}$ & $\begin{array}{c}\text { Load sites considered for inclusion in } \\
\text { SPARROW nutrient models } \\
\text { (TN/TP) }\end{array}$ \\
\hline United States & 32,855 & 3,265 & $931 / 1,064$ \\
Canada & 1,768 & 736 & $392 / 408$ \\
\hline
\end{tabular}




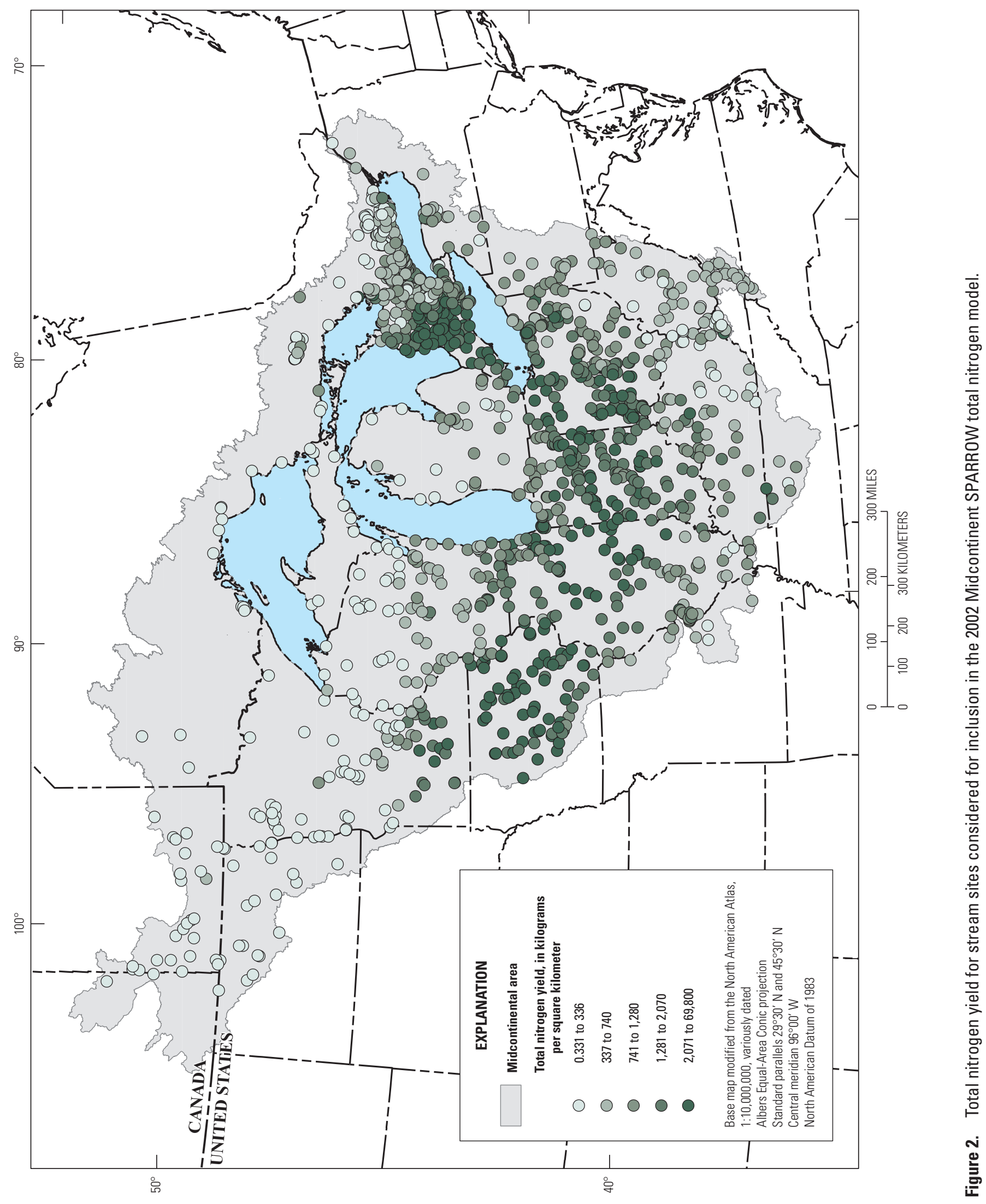




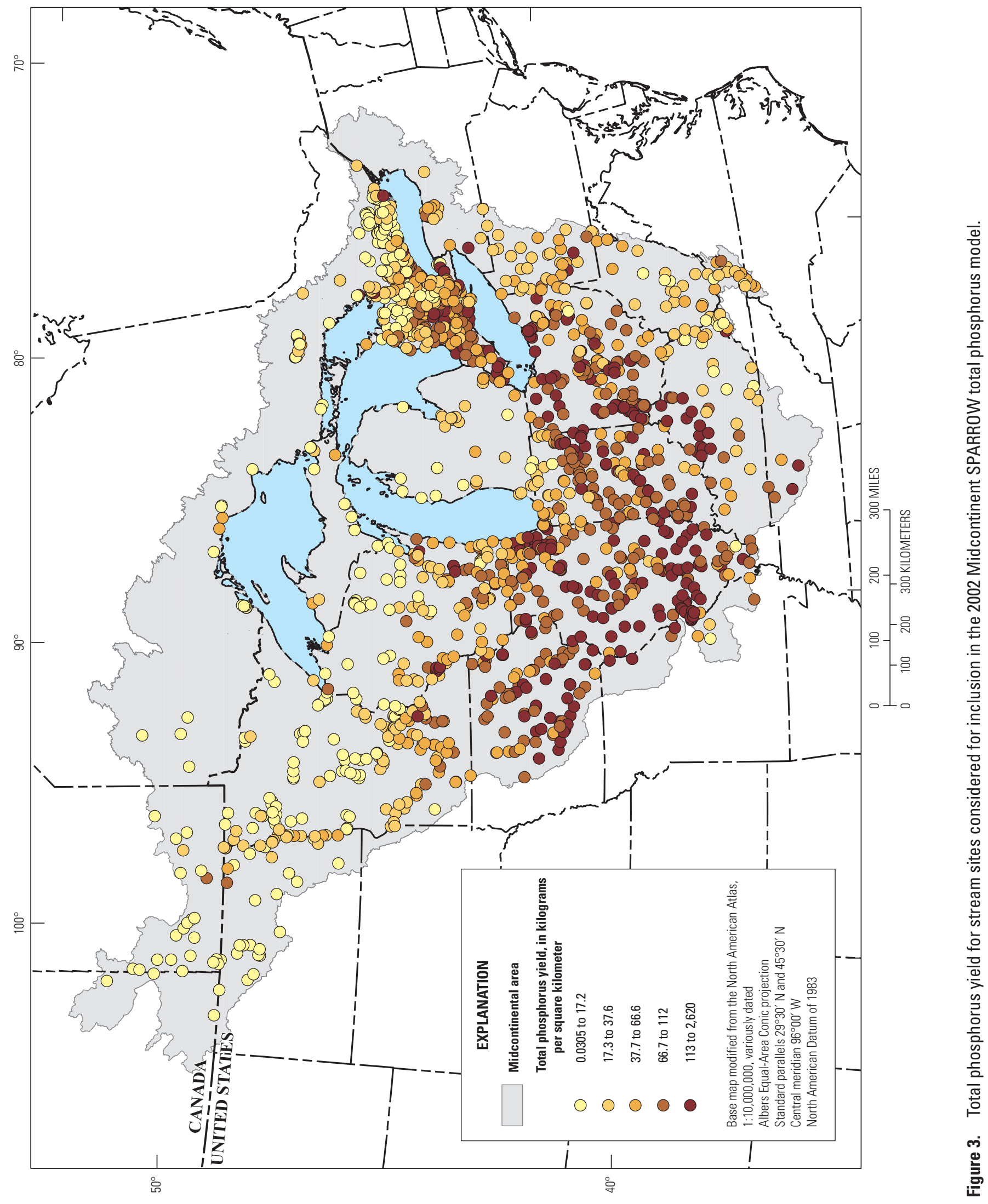




\section{Summary}

A rigorous screening and evaluation procedure was applied to reduce nearly 35,000 sites with available nitrogen and phosphorus data to a select a set of approximately 1,500 sites. For these 1,500 sites, concentration and streamflow data were of sufficient quality and quantity to be suitable for long-term total nitrogen (TN) and total phosphorus (TP) load estimation. Load estimates from these suitable sites will be considered for inclusion as calibration targets in the 2002 Midcontinent Nutrient SPAtially Referenced Regressions on Watershed attributes (SPARROW) models. The resulting set of qualified $\mathrm{N}$ and $\mathrm{P}$ concentration and streamflow data represents a significant by product of the Midcontinent load estimation effort - a by product that could provide considerable utility in other regional or local water-quality assessments. The final load sites considered for use in SPARROW models represent a wide range in watershed sizes, $\mathrm{N}$ and $\mathrm{P}$ source inputs, and land-use and watershed characteristics in the Midcontinental region. The distribution of sites covers most of the area, but the density of sites is relatively low in northern forested areas, especially in the Province of Ontario, north of Lakes Huron and Superior. The density of sites is highest in southeast Ontario, between Lakes Huron and Erie. Highest mean-annual TN and TP yields were observed in the humid, agricultural areas of the Midcontinental region, in a band that stretches from Iowa; through Illinois, Indiana, and Ohio; and into southeast Ontario. The lowest TN and TP yields were in the north, northwest, and southeast portions of the region. Low nutrient yields in these areas are associated with relatively low $\mathrm{N}$ and $\mathrm{P}$ source inputs or low precipitation, or both.

\section{References Cited}

Benoy, G.A., Jenkinson, W., Robertson, D.M., and Saad, D.A., 2016, Nutrient delivery to Lake Winnipeg from the RedAssiniboine River Basin - A binational application of the SPARROW Model: Canadian Water Resources Association, v. 41, no. 3, p. 429-447, accessed February 2018 at https://doi.org/10.1080/07011784.2016.1178601.

Carpenter, S.R., Caraco, N.F., Correll, D.L., Howarth, R.W., Sharpley, A.N., and Smith, V.H., 1998, Nonpoint pollution of surface waters with phosphorus and nitrogen: Ecological Applications, v. 8, no. 3, p. 559-568.

Clark, B.J., and Sellers, T.J., 2014, Rainy-Lake of the Woods state of the basin report, 2nd Edition: Lake of the Woods Sustainability Foundation, 225 p., accessed February 2018 at https://lowwsf.com/sobr.

Cochran, W.G., 1977, Sampling techniques (third ed.): Wiley, New York.
Cohn, T.A., 2005, Estimating contaminant loads in riversan application of adjusted maximum likelihood to type 1 censored data: Water Resources Research, v. 40, no. 7 , W07003.

Dodds, W.K., and Smith, V.H., 2016, Nitrogen, phosphorus, and eutrophication in streams: Inland Waters, v. 6 , no. 2 , p. $155-164$.

Environment and Climate Change Canada (ECCC), 2016, HYDAT database: National water data archive, accessed February 2018 at https://ec.gc.ca/rhc-wsc/default. asp?lang=En\&n=9018B5EC- 1 .

Government of Canada, 2018, National Hydro Network, accessed April 12, 2018, at https://open.canada.ca/data/en/ dataset/a4b190fe-e090-4e6d-881e-b87956c07977.

Hirsch, R.M., 2014, Large biases in regression-based constituent flux estimates - causes and diagnostic tools: Journal of the American Water Resources Association, v. 50, no. 6, p. 1401-1424, accessed February 2018 at http://onlinelibrary.wiley.com/doi/10.1111/jawr.12195/full.

Hirsch, R.M., Moyer, D.L., and Archfield, S.A., 2010, Weighted regressions on time, discharge, and season (WRTDS), with an application to Chesapeake Bay River inputs: Journal of the American Water Resource Association, v. 46 , no. 5, p. 857-880.

Horizon Systems Corporation, 2018, NHDPlus Version 2, accessed April 12, 2018, at http://www.horizon-systems. com/nhdplus/NHDPlusV2_home.php.

Jenkinson, R.W., and Benoy, G.A., 2015, Red-Assiniboine basin SPARROW model development technical document: National Research Council of Canada, 65 p., accessed February 2018 at http:/www.ijc.org/files/publications/ IJC\%20RA\%20Model\%20Development\%20Report $\% 20$ 2015\%20FINAL.pdf.

Lee, C.J., Hirsch, R.M., Schwarz, G.E., Holtschlag, D.J., Preston, S.D., Crawford, C.G., and Vecchia, A.V., 2016, An evaluation of methods for estimating decadal stream loads: Journal of Hydrology, v. 542, p. 185-203, accessed February 2018 at http://doi.org/10.1016/j.jhydrol.2016.08.059.

Michalak, A.M., and others, 2013, Record-setting algal bloom in Lake Erie caused by agricultural and meteorological trends consistent with expected future conditions: Proceedings of the National Academy of Sciences, v. 110, no. 16, p. 6448-6452.

Moore, R.B., and Dewald, T.G., 2016, The road to NHDPlus-Advancements in digital stream networks and associated catchments: Journal of the American Water Resources Association, v. 52, no. 4, p. 890-900, accessed February 2018 at http://onlinelibrary.wiley.com/doi/10.1111/1752$1688.12389 /$ abstract. 
Natural Resources Canada, 2009, National Hydro Network (NHN): accessed February 2018 at https://open.canada.ca/ data/en/dataset/a4b190fe-e090-4e6d-881e-b87956c07977.

North American Atlas, 2018, Hydrography data, accessed April 12, 2018, at https://www.sciencebase.gov/catalog/ item/4fb55df0e4b04cb937751e02.

North American Atlas, 2018, Political boundaries, accessed April 12, 2018, at https://www.sciencebase.gov/catalog/ item/4fb555ebe4b04cb937751db9.

Preston, S.D., Alexander, R.B., Woodside, M.D., and Hamilton, P.A., 2009, SPARROW modeling - enhancing understanding of the Nation's water quality: U.S. Geological Survey Fact Sheet 2009-2019, 6 p.

Robertson, D.M., and Saad, D.A., 2011, Nutrient inputs to the Laurentian Great Lakes by source and watershed estimated using SPARROW watershed models: Journal of the American Water Resources Association, v. 47, no. 5, p. 10111033, accessed February 2018 at http://onlinelibrary.wiley. com/doi/10.1111/j.1752-1688.2011.00574.x/abstract.

Robertson, D.M., and Saad, D.A., 2013, SPARROW models used to understand nutrient sources in the Mississippi/ Atchafalaya River Basin: Journal of Environmental Quality, v. 42, no. 5, p. 1422-1440, accessed February 2018 at https://doi.org/10.2134/jeq2013.02.0066.

Runkel, R.L., Crawford, C.G., and Cohn, T.A., 2004, Load estimator (LOADEST) - A FORTRAN program for estimating constituent loads in streams and rivers: U.S. Geological Survey Techniques and Methods book 4, chap. A5.

SAS Institute Inc., 2004, SAS Documentation, Version 9.1.3: SAS Institute Inc., Cary, North Carolina.
Saad, D.A., Benoy, G.A., and Robertson, D.M., 2018, Waterquality and streamflow datasets used for estimating loads considered for use in the 2002 Midcontinent nutrient SPARROW models, Canada and the United States, 1970-2012: U.S. Geological Survey data release, https://doi.org/10.5066/F7VT1R1K.

Saad, D.A., Schwarz, G.E., Robertson, D.M., and Booth, N.L., 2011, A multi-agency nutrient dataset used to estimate loads, improve monitoring design, and calibrate regional nutrient SPARROW models: Journal of the American Water Resources Association. v. 47, no. 5, p. 933-949, accessed February 2018 at https://doi.org/10.1111/j.17521688.2011.00575.x.

Schindler, D.W., Hecky, R.E., and McCullough, G.K., 2012, The rapid eutrophication of Lake Winnipeg - Greening under global change: Journal of Great Lakes Research, v. 38 , p. 6-13.

Schwarz, G.E., Hoos, A.B., Alexander, R.B., and Smith, R.A., 2006, The SPARROW surface water-quality model-theory, applications and user documentation. U.S. Geological Survey Techniques and Methods, book 6, chap. B3, accessed February 2018 at https://pubs.usgs.gov/tm/2006/tm6b3.

Smith, V.H., 2003, Eutrophication of freshwater and coastal marine ecosystems a global problem: Environmental Science and Pollution Research, v. 10, no. 2, p. 126-139.

U.S. Environmental Protection Agency, 2000, Nutrient criteria technical guidance manual-Lakes and reservoirs: Office of Water, EPA-822-B-00-001.

U.S. Environmental Protection Agency, 1998, National strategy for the development of regional nutrient criteria: Office of Water, EPA-822-R-98-002, 47 p.

U.S. Geological Survey, 2017, USGS Water Data for the Nation: accessed February 2018 at https://waterdata.usgs. gov/nwis. 

Appendix 1 
Table 1-1. Sampling agencies associated with water-quality data used to calculate load estimates considered for use in 2002 Midcontinent SPARROW Models.

Agency name

Agriculture and Agri-Food Canada

City of Winnipeg Water and Waste Water Department, Manitoba

Environment and Climate Change Canada

Green Bay Metropolitan Sewerage District, Wisconsin

Heidelberg University

Illinois Environmental Protection Agency

Indiana Department of Environmental Management

Iowa Department of Natural Resources

Iowa State University, Des Moines River Water Quality Network

Kentucky Department of Natural Resources and Environmental Protection

Manitoba Sustainable Development

Maryland Department of Natural Resources

Maryland Department of the Environment

Metropolitan Council Environmental Services, Minnesota

Michigan Department of Environmental Quality

Minnesota Pollution Control Agency

National Park Service

New York Department of Environmental Conservation

North Carolina Department of Environmental Quality

North Dakota Department of Health

Ohio Environmental Protection Agency

Ohio River Valley Water Sanitation Commission (ORSANCO)

Ontario Ministry of the Environment and Climate Change

Pennsylvania Department of Environmental Protection

Saskatchewan Ministry of Environment

South Dakota Department of Environment and Natural Resources

Tennessee Department of Environment and Conservation

U.S. Army Corps of Engineers

U.S. Forest Service

U.S. Geological Survey

Virginia Department of Environmental Quality

West Virginia Department of Environmental Protection

Western Lake Superior Sanitary District

Wisconsin Department of Natural Resources 
For additional information contact:

Director, Upper Midwest Water Science Center U.S. Geological Survey

8505 Research Way

Middleton, WI 53562

https://wi.water.usgs.gov

Publishing support by:

The Madison and Pembroke Publishing Service Centers 
$\stackrel{\circ}{\vec{P}}$

言

$\overrightarrow{\mathrm{g}}$

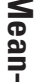

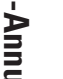

产

言

$\vec{F}$

कू

ङ

홍.

임

s

D 